\title{
THE MISSION STATEMENT AS A DRIVER OF STRATEGY FORMULATION IN HIGHER EDUCATION INSTITUTIONS
}

\author{
A MISSÃO COMO DIRECIONADOR DA ESTRATÉGIA EM INSTITUIÇÕES DE ENSINO SUPERIOR \\ LA MISIÓN COMO DIRECCIONADOR DE LA ESTATEGIA EN INSTITUCIONES DE ENSEÑANZA SUPERIOR
}

\author{
ANGELA MARIA HABERKAMP \\ Phd Candidate \\ Universidade do Vale do Taquari- Brazil \\ angelamh@univates.br \\ ORCID: http://orcid.org/0000-0001-7598-7661 \\ NORBERTO HOPPEN \\ Doctor \\ Universidade do Vale dos Sinos - Brazil \\ norbertohoppen@gmail.com \\ ORCID: http://orcid.org/0000-0003-1827-8695 \\ CARLOS ALBERTO DIEHL \\ Doctor \\ Universidade do Vale dos Sinos - Brazil \\ carlosadiehl@gmail.com \\ ORCID: http://orcid.org/0000-0002-2382-6070
}

Submitted on: 23/10/2017

Approved on: 23/04/2018

Doi: alcance.v25n2(Mai/Ago).p126-141

\begin{abstract}
This study aims to identify whether and how Brazilian higher education institutions (HEls) are using organizational mission statements as drivers of strategy. Based on the effectiveness of the mission model proposed by Pearce and David (1987), this paper presents a content analysis of the mission statements of ninety-one HEls, based on information available on their websites. The results show that philosophy, type of service, and self-concept are the most frequent elements found, and that none of the ninety-one mission statements analyzed featured more than six out of the eight elements of the conceptual model. This denotes only a partial use of mission statements as strategy drivers in HEls. Moreover, as a consequence of the specificities of the educational sector and of the Brazilian regulations, two new elements have been added to the original conceptual model (with more than 560 citations in Google Scholar): graduates' profile and contribution to the community, making the conceptual model more aligned with the specificities of HEls. These results can be used by HEls to improve the formulation of their mission statements and enhance their effective use as strategy drivers.
\end{abstract}

Keywords: Strategic driver. Mission statement. Higher education institution.

\section{RESUMO}

Este estudo tem como objetivo identificar se e como as instituições de ensino superior (IES) brasileiras estão utilizando a missão organizacional como direcionadora da estratégia. Com base no modelo de efetividade da missão proposto por Pearce e David (1987), foi realizada uma análise de conteúdo das missões de 91 IES, a partir de informações disponibilizadas em seus sites. Os resultados mostram que a filosofia da IES, o tipo de serviço e 
o conceito próprio são os elementos usados com maior frequência e que nenhuma das 91 missões analisadas apresenta mais de seis dos oito elementos do modelo conceitual de efetividade das missões. Isso indica um uso parcial da missão como direcionadora de estratégia em IES. Ainda, dadas as especificidades das IES, dois novos elementos foram encontrados - perfil do egresso e contribuição com a comunidade -, adequando melhor o modelo conceitual de Pearce e David (que possui mais de 560 citações no Google Scholar) às especificidades das IES. Os resultados encontrados podem ser utilizados pelas IES para melhorar a formulação de suas missões e o seu uso efetivo como direcionador da estratégia.

Palavras chave: Direcionador estratégico. Declaração de missão. Instituições de ensino superior.

\section{RESUMEN}

Este estudio tiene como objetivo identificar como las instituciones de enseñanza superior (IES) brasileñas están utilizando la misión organizacional como direccionadora de la estrategia. Con base en el modelo de efectividad de la misión propuesto por Pearce y David (1987), fue realizado un análisis de contenido de las misiones de 91 IES, a partir de informaciones disponibles en sus páginas webs. Los resultados muestran que la filosofía de la IES, el tipo de servicio y el concepto propio son los elementos usados con mayor frecuencia y que ninguna de las 91 misiones analizadas presentan más de seis de los ocho elementos del modelo conceptual de efectividad de las misiones. Ello indica un uso parcial de la misión como direccionadora de la estrategia en IES. Aún, dadas las especificidades de las IES, dos nuevos elementos fueron encontrados - perfil del egreso y contribución con la comunidad -, adecuando mejor el modelo conceptual de Pearce y David (que posee más de 560 citaciones en Google Scholar) a las especificidades de las IES. Los resultados encontrados pueden ser utilizados por las IES para mejorar la formulación de sus misiones y su uso efectivo como direccionador de la estrategia.

Palabras clave: Direccionador estratégico. Declaración de misión. Instituciones de enseñanza superior.

\section{INTRODUCTION}

Higher education in Brazil is heterogeneous, being offered by universities, university colleges or centres, colleges, higher education institutes, and technological education centres, in both the private and public sectors (OLIVEIRA, 2014). These institutions often face conflicting objectives, such as a focus on schooling or on research. Therefore an effective strategic planning, in which the mission statement acts as a driver of the direction taken by the institution, is a key management tool. Also, the regulations of higher education institutions (HEls) mention the need for an institutional strategic planning, and mission statements that are aligned with the economic, social, cultural, and research \& development context of the region and the nation as a whole (Ldb, 1996; Sinaes, 2004; Pdi, 2006).

Following the example of other countries, Brazil has seen a growth in the number of HEls and registered students in recent decades. There are 2,678 institutions with distinct characteristics, 129 of them operating in the southern Brazilian State of Rio Grande do Sul (RS) ${ }^{1}$. In comparison with the Brazilian context, RS has a lower proportion of private for-profit compared to private non-profit (community based and religious) HEls (Koppe, 2014). Both types of institutions have the common goal of providing higher education, but they also have different characteristics that should be reflected in their strategies. Non-profit community-based institutions can be potentially indicative of a diversity of elements in the mission statement. Non-profit HEls could somehow be treated as nonstate public institutions, being recognized by regional communities as an important development factor (Comung, 2014). In contrast, the focus of for-profit HEls is on profitability (Castro, 2014,) and they should reveal more homogeneous strategies.

In view of aspects related to the administrative category (public, private non-profit and private for-profit) and the type of academic organization (college, technological institute, university college or centre, or university), it appears that HEls have different objectives: provision of educational services, promotion of research, maintenance of educational activities, or remuneration of investors. Each institution must define what is essential. For this, strategic plans aligned with the management actions are essential.

${ }^{1}$ http://emec.mec.gov.br 
Reviewing the effectiveness of mission statement in Brazilian federal technical institutes, Freitas et al. (2011) identified that none of them has an effective mission statement. That means that the mission statement is not always used as a strategy driver in Brazilian HEls. In this context, the research question that motivates this research is: "whether and how are the mission statements of HEls used as strategy drivers?"

Establishing the mission statement is the first step in the planning processes, to set the goals and priorities. The mission statement represents the organization's identity (Forte \& Pereira, 2003). However, it seems that the objectives of HEls are not always clearly defined. In a case study, Espartel (2009) identified that graduates of an $\mathrm{HEl}$ perceived little difference between the undergraduate program they were taking and undergraduate programs of other HEls. The low differentiation between undergraduate programs offered by different $\mathrm{HEls}$ may indicate a failure to communicate the institutional mission statement, or it may indicate a lack of alignment between strategic planning and management. Therefore, a detailed knowledge of the essence and content of the institutional mission statement is a key factor in making this process efficient, and capable of fulfiling its purpose as part of the strategic planning process (Mussoi, Lunkes, \& Silva, 2010).

Pearce (1982) states that organizations must set out their mission statements when attempting to meet their perceived social responsibility, because different approaches reflect differences in competitive positioning. In other words, the mission statement should mirror situational factors and priorities established by the stakeholders of the organization. Considering this assumption, and the research question, the main objective of this study is to analyze whether and how the mission statement is an effective driver of strategic planning in Brazilian HEls. To operationalize this analysis, we adopted the basic mission statement effectiveness model proposed by Pearce and David (1987). This influential model has more than 560 citations in Google Scholar (accessed on September 27, 2017) and was also used more recently by Fitzgerald and Cunningham (2016).

The relevance of this study is related to the importance of mission statements to determine how organizations describe their strengths, purposes, goals and objectives to all stakeholders. In addition, the Institutional Development Plan of HEls (Pdi, 2006) is mandatory for Brazilian HEls to obtain accreditation. The PDI states that mission, objectives and goals are important requirements for revealing purposes and priorities concerning educational and social features to stakeholders: government, regional communities, students, employees, etc. Thus, well-prepared mission statements can bring benefits to the institutions, assisting them in accomplishing their goals and reinforcing their image as educational institutions to their stakeholders (Mussoi, Lunkes, \& Silva, 2010). This study also highlights gaps relating to the intentions of HEls that should be emphasized in their mission statements. Additionally, our study discusses whether Pearce and David's model is suited to specific sectors, in particular, special regulated sectors with normative guidelines.

This article is structured in five sections, including the introduction. Section 2 defines the theoretical framework including the concept of mission statement in the context of strategy, a discussion of previous studies, and a discussion of the mission statement effectiveness model developed by Pearce and David (1987). Section 3 describes the methodology, based on a qualitative analysis of mission statement contents to identify the elements of the conceptual model adopted. Section 4 presents the results obtained: the terms adopted in the mission statements, and the effectiveness of the mission statement effectiveness. As concluding remarks, Section 5 discusses the results and main contributions and offers some suggestions for further research.

\section{THEORETICAL BACKGROUND}

\subsection{Mission statements and HEls}

The mission statement of an organization has different definitions. For Drucker (1986), it forms the basis for priorities, strategies, plans and tasks, differentiating one organization from another. The mission statement is essential for the structuring of the organisation's goals and strategies.

Pearce (1982) defines mission statement as a broad statement that summarizes the purpose of the organization. It distinguishes businesses in the same field of activity, and identifies the scope of operations of an organization. For the author, the institutional mission statement does not only incorporate the philosophies of strategic decisions, it also reveals the image that the organization is seeking to project, its self-concept and its sphere of operation, indicating the products and services that aim to satisfy consumer's needs.

The mission statement should reveal the rationale of the organization, providing key information, such as the products and services offered, the main target markets, concerns about growth, efficiency, employees, shareholders, the environment and long-term profitability (Pearce \& David, 1987). Summarizing earlier concepts,

Revista Alcance - Eletrônica - vol. 25 - n. 2 - Mai./Ago. 2018 
King, Case and Premo (2012) define the mission statement as comprising all the main features of the business, including its purpose, unique strengths, values, critical interests, goals and core objectives.

For HEls, the mission statement forms the academic grid by which it will be assessed (Ellis \& Miller, 2014), leading to a continuous need for review and adjustment. This situation is identified within the Brazilian context. The regulation, supervision and assessment of Brazilian HEls is based on laws, decrees and ordinances - National Higher Education Evaluation System (Sinaes, 2004), Institutional Development Plan (PDI, 2006) and Assessment Instruments (Inep, 2015).

These norms mention the need for an institutional strategic planning, and for mission statements that are aligned with the economic, social, cultural, and research \& development context of the region and the nation. Moreover, the mission statement is a mandatory element of the Institutional Development Plan and of the Assessment Instruments, contributing to the definition of institutional actions and their academic-educational activities, research, social and cultural development and management. The mission statement is also a valuable source of data enabling interested parties to reflect on the purpose of the HEls, make comparisons between them, and monitor changes over time (Stemler, Bebell, \& Sonnabend, 2011).

Brazilian HEls are organized as colleges, university colleges or centres, universities (Sinaes, 2004) or federal institutes of education, science and technology (Law 11.892, from December 29, 2008). In terms of administrative category, they can be classified as private for-profit, private non-profit or public institutions (Law 9.394 of December 20, 1996).

\subsection{Mission statements in the context of strategy}

As a strategic tool, the mission statement specifies the organization's goals, aligning them, consolidating the values over time, overlapping individualism and interest groups, and creating a sense of expectations shared among all levels of employees (Pearce, 1982). This is especially important for HEls where individuals from different backgrounds and hierarchical levels need to operate together, while balancing their interests with those of the students.

Conceptually, mission statements represent a long-term articulation between the internal and external stakeholders of organizations (Fitzgerald \& Cunningham, 2016). The benefits of mission statements are directly related to the impact on the organization (Teles \& Lunkes, 2009). Despite the importance of this subject, according to Fitzgerald and Cunningham (2016), the academic literature on this topic is limited.

These authors also identified three fundamental purposes of mission statements: as a guide for decision making, as a communication tool, and as a tool to guide the formulation and implementation of strategic planning. In this context, some studies (e. g. Drucker, 1983; Campbell, 1991) sought to understand and describe the purpose of mission statements. Others, such as Want (1986), Pearce and David (1987) and Palmer and Short (2008), advocated the presence of some minimum components of mission statements that could contribute to the formulation of the strategy and to the development of the organization.

In this research, we studied the mission statement as an effective driver of strategic planning, and investigated whether there are any differences between the mission statements of HEls, according to their academic organization and administrative category. Among the models developed to evaluate the effectiveness of mission statements, we chose the one proposed by Pearce and David (1987), which contains elements that are important when assessing the effectiveness of a mission statement, namely:

- Principal products/services;

- Target customers and markets;

- Core technologies;

- Commitment to growth, survival and profitability;

- Philosophy;

- Desired public image;

- Self-concept;

- Geographic domain.

The adoption of this model stems from its comprehensive structuring based on eight different elements. In addition, this model has been used in nationwide studies (Ellis \& Miller, 2014; Dörtyol, 2015; Fitzgerald \& Cunningham, 2016), allowing a comparison of their results with those of our study. 
King, Case and Premo (2012) studied the content of the mission statements of organisations in different countries in 2001, 2008, 2010 and 2011, comparing the results. Their study identified stakeholders, objectives and targets. Although some stakeholders are mentioned regularly throughout the study period (customers, communities, shareholders and employees), others have gained significance, showing that the inspirational factors of the belief system can be changed. This trend was also identified in relation to the goals and objectives.

Because of their origin and conception, public and private organizations have different focuses. Leggat and Holmes (2015) analyzed the content of the mission statements, vision and values of the Australian public and private hospitals, inorder to better understand their focus. In public organizations, the analysis revealed a focus on communication, in order to reinforce their legitimacy and identity. In private organizations, a greater focus on competitive strategy and the provision of guidelines for employees was identified.

Despite being a starting point for the business strategic formulation and the synthesis of its fundamental purpose (Pearce \& David, 1987), some studies identified that the mission statement is not always used effectively. Bartkus and Glassmann (2008) concluded that institutional interests motivate the inclusion of specific stakeholders in the mission statements, and social issues related to political decisions are hierarchically higher than the sustainable and responsible decisions. Souza, Coral and Lunkes (2014) identified that hotels in Southern Brazil do not have an effective mission statement and that the mission statement is used more as an advertising management tool than as a strategic tool.

The mission statements of HEls had been studied following different approaches. Forte and Pereira (2003) found a limited use of the mission statement as a basis for strategic decisions of the universities in the State of Ceará (Brazil), and that is rarely disclosure between the parties involved. Consequently, students, staff, teachers and administrators lack knowledge of the mission statements. Elements related to the type of service offered and customers were those most mentioned.

Ellis and Miller (2014) examined the statements concerning mission statements of seven higher education institutions in Jamaica, and found that some do not reflect the principles and objectives of Education for All, conceptualized by UNESCO in 2013. The authors concluded that while HEls demonstrate some affirmation of Education for All as a whole, their mission statements do not, therefore they need to be reconsidered, and in some instances simplified, to reflect the goals more closely.

Another study of HEls, conducted in Ireland, by Fitzgerald Cunningham (2016), identified the presence of two principal elements of mission statements: target customers and markets and principal services. The researchers also identify positive correlations between patents and the number of components of the mission statement, and between the allowances admitted to Ireland and the number of components of the mission statement.

Comparing the mission statements from 2012-2013 with 2004, Ayers (2015) identified that when statements reflect the institutional logic, they demonstrate how the institution relates to their environment. Thus, routines and practices at the organizational level related to accreditation structures, pedagogies, practices and curriculum goals must be viewed not only as technical organizational strategies but as practices to sustain the legitimacy of an institutional environment with inconsistencies and that is continuously evolving.

Penco, Profumo and Scarsi (2018) studied the mission statements of cruise ships, seeking to understand the characteristics of the specific content and the stakeholder orientation. The results show that the mission statements are usually structured as very simple documents, and the most commonly cited stakeholders are Customers, followed by Employees. The authors concluded that, following the existing literature, a typical mission statement does not exist, because each cruise company tends to construct a different mission statement. Moreover, the studied mission statements failed to include all the topics recommended by previous studies

\section{METHOD}

Our study investigates the effectiveness and content of the mission statements used by HEls. In Brazil, non-profit private institutions account for $44 \%$ of HEls, while in RS they represent $57 \%$ (http:emec.mec.gov.br). This could influence higher education in the state, giving it distinct characteristics, with implications on the operational strategies and therefore on the mission statements of the institutions.

We started our research by classifying the HEls of RS. We found 129 institutions (our sample). Of these 119 were classified as private and 10 as public. Concerning the academic organization, there are 102 Colleges, 
five University Colleges or Centres, 19 Universities and three Federal Institutes. Subsequently, we visited the websites of these 129 institutions and transcribed their mission statements to a file that included name, category, academic organization and the text of the mission statement. Some HEls operate as corporate universities, with educational units located in different cities, having the same or different mission statements. When the mission statement of different educational units was the same, we considered the text only once. This led to the exclusion of 12 institutions. During the period studied (June 2015), we were not able to identify mission statements for 26 institutions. Thus, we finally analyzed 91 mission statements. We then categorized the 96 institutions in aprioristic form, based on the academic configuration and administrative category, classifying them. The mission statements were grouped into seven categories: public, private for-profit, private non-profit and colleges, university colleges or centres, federal institutes and universities.

Next, we codified the basic statements of the mission statements, based on the elements of the mission effectiveness model of Pearce and David (our ex-ante categories) as follows:

- Services offered: clearly specified services (undergraduate and graduate degree programs, executive education, theological training, etc.), and generic (education, teaching, etc.);

- Market or consumers: to whom the service is intended (institute members, people, community, etc.);

- Technology: infrastructure, information and communication technology used to facilitate the teachinglearning process;

- Growth, survival and profitability: specification of how the HEls intend to grow and achieve profitability, investor relations (sustainable, customer satisfaction, etc.) and information about the monthly fee;

- Philosophy: definition of priority objectives, beliefs and values (forming conscious citizens, educating for work, etc.);

- Desired public image: identification of how the HEls would like to be and be seen (being, desire);

- Self-concept: adjectives that describe the institutions and the services they offer (e.g. quality, excellence, etc.);

- Geographic domain: where the HEls operate.

We also performed an exploratory analysis using the word cloud technique (Atenstaedt, 2012) and text mining, enabling us to summarize a set of texts, which are presented by grouping the concepts, showing the most frequent ones and their connections (Araújo Júnior \& Tarapanoff, 2006). Other studies have also used text mining to analyze mission statements, e.g. Alshameri, Greene and Srivastava (2012) and Allison, (2017).

Certain words were present in a significant number of mission statements that did not fit with the eight elements of Pearce and David. These were classified into two additional categories: graduates' profile and contribution of HEls with the community/environment. Therefore, we performed an additional codification, identifying the mission statements where the new elements were present.

With the aim of improving the reliability of the coding and analysis process of our data (Neuendorf, 2002), an additional analysis was performed by one of the researchers two weeks after the initial analysis. The resulting percentage of agreement was high (more then $85 \%$ ), and discrepancies were adjusted.

Both codifications and hermeneutic analyses were performed with the support of Nvivo®. This software helped us to codify, classify and sort non-numerical data, examining relationships in that data, and combining the analysis with linking, shaping, searching and modelling.

The hermeneutic analysis showed the most used terms in the mission statements, and the codification based on the conceptual model (and in the additional categories) enabled us to identify the most frequent elements. The mission statements were then compared, considering the administrative category and academic organization. The results were analyzed and compared with previous studies.

\section{RESULTS}

We divided our results into two major groups: those stemming from the hermeneutic analysis, where we identified the most frequently used terms; and those related to the effectiveness of the mission statement, with the identification of the elements, according to the effectiveness of the mission statement analysis model. 


\subsection{Hermeneutic analysis by administrative category and academic organization}

One aspect assessed is the length of the mission statement. There is no specific rule as to its length, but organizations must be careful not to make their mission statements too long or too short, or lose focus, missing out important elements that guide the organization (Bart, 2006). In general, the mission statement must be long enough to achieve its purpose (Abrahams, 2013).

First, we described the entire range of mission statements investigated, identifying some general characteristics. Through word frequency analysis, we found 1787 words (excluding those with less than three letters, articles, prepositions, and words like in, of, with, etc.), with an average length of 18 words per statement. The shortest had five words, and the longest 77 , which demonstrates that there is no standard or reference with respect to the length. All the statements together contained 703 different words, generating an occurrence/word ratio of 2:54, showing that the basic repertoire is quite varied. These ratios show that there is a very rich linguistic range contained in the statements (Bardin, 2011).

The word with the highest number of occurrences was development (47), followed by promoting, formation, knowledge and social $(35,34,31$ and 31 occurrences, respectively). Figure 1 shows the words present in the mission statements, their size being proportional to their frequency.

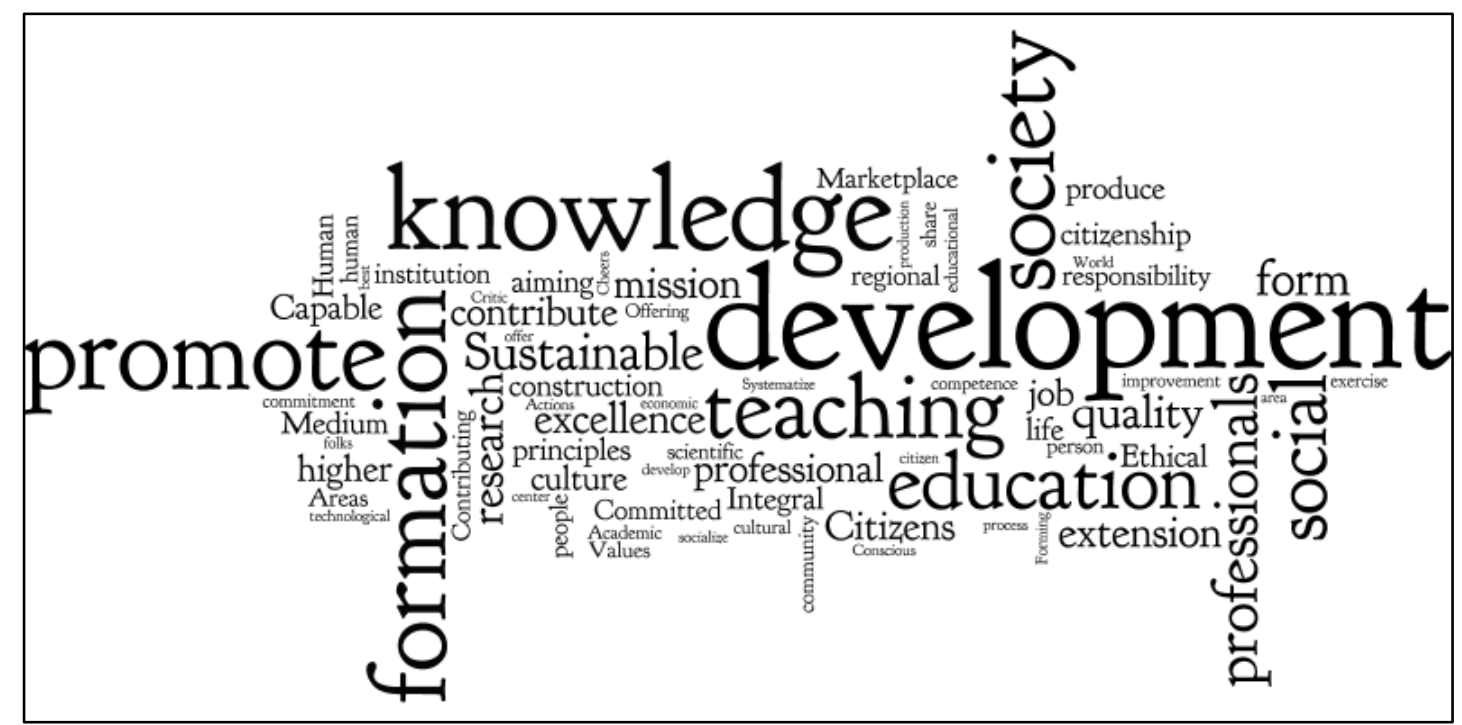

Figure 1: Cloud with mission statement words Source: Elaborated by the authors.

By segmenting the mission statements based on the academic configuration of HEls there is, in general, an uniformity among the most frequently used words. However, they do not appear in the same order: knowledge and development (universities), development and education (university or college centres) and training and development (colleges and federal institutes), indicating that the institutions focus their goals on different elements. Accepting that the HEls develop a strategy aimed at achieving their main specific objectives, it is consistent that the mission statement keywords are distinct, since the main reasons are, by definition, different.

Comparing the role of public, private for-profit and non-profit institutions, we realize that only among private for-profit $\mathrm{HEls}$, the word related to the type of service provided is among the most quoted, along with development and society. In private non-profit HEls, development, training and society are the most cited, and in public institutions appears to promote knowledge and development. It is worth noticing that there is no significant difference in the mission statement between for-profit and non-profit private institutions, showing that financial return is not considered a principal objective, or at least, this is not explicit in the mission statement.

\subsection{The effectiveness of HEls'mission statements}

We evaluated each institutional mission statement, analyzing its effectiveness elements based on Pearce and David's model. Table 1 shows the elements identified and the number of occurrences. 
Table 1

Frequency of Mission Statement Effectiveness Elements

\begin{tabular}{l|c}
\hline Element & Occurrences \\
\hline Philosophy & 67 \\
\hline Service type & 42 \\
\hline Self-concept & 35 \\
\hline Consumers or markets & 22 \\
\hline Geographic domain & 14 \\
\hline Desired Public image & 9 \\
\hline Survival, growth, profit & 7 \\
\hline Technology & 1 \\
\hline Soure: Elaboted by thaulhors & \multicolumn{1}{c}{} \\
\hline
\end{tabular}

Source: Elaborated by the authors

Of the 91 mission statements investigated, 42 mention the type of service provided, which are, for the most part, defined generically, such as education. Only one institution specifies the types of degree programs and certificates: Undergraduate, Graduate and Executive education. Our study details the description of the institutions' mission statements that offer specific services such as theological training, education, research and executive education in the field of Information Technology. Amongst the Federal Institutes, 100\% identify the type of service provided. The result confirms neither the findings of Forte and Pereira (2003), where service type was among the most mentioned elements, nor the findings of Ellis and Miller (2014), which did not identify any reference regarding the type of service offered.

We found a primary market in only $24 \%$ mission statements. We identify this element better when the institution services are available to a specific group, such as "members of Institutes of Consecrated Life, candidates for the Priestly Ministry and leaders of Christian communities" or "areas of activity within the cooperatives." However, in the study, we found generic expressions such as students and alumni. The University Colleges or Centres do not identify this element, while the Federal Institutes and Private for-profit institutions identify it more frequently (both with $33 \%$ ). Despite the fact that this element is practically not identified, it is present in the mission statements in another way: under the description of the graduates' profile, which is not included in the model employed, but discussed in more detail below.

The technology used is the least quoted element. Only the mission statement of a non-profit private university mentions it. Although the use of technology occurs at the global level in educational institutions (MORAIS et al., 2014), it seems that it is not being used towards increasing innovation in the education and learning process. One reason for this may be the barrier faced by faculty in the use of technological resources (Oye, lahad, \& Rahim, 2012). Alternatively, the institutions do not see technology as a strategic resource, able to provide a competitive advantage, but rather as a support tool.

The fourth element analyzed deals with survival, growth and profit. With the emergence of distance education and corporate universities, new challenges regarding the issue of sustainability arise (Braga \& Monteiro, 2005).

In RS, historically the private for-profit institutions have a lower participation than in other regions of the country, in comparison with public and private non-profit institutions (Koppe, 2014). For Braga and Monteiro (2005), this may indicate a relatively adverse environment for expansion, reflected in the decisions of these institutions and their operational strategy. Because the for-profit institutions face competition from private non-profit institutions, they need to define alternative strategies, leading to a more aggressive positioning to increase their share (Paiva et al., 2014).

Based on this, we expected to identify a significant difference regarding the presence of elements related to survival, growth and profit in the mission statement of the for-profit institutions in comparison to the others. However, this was not borne out in results. Only five colleges ( 2 private non-for-profit and 3 for-profit) presented them in their mission statements. The only explicit reference for this element was found in the mission statement of a private college, "promoting the satisfaction of customers, employees, investors and society". Specifically, in relation to this element, the mission statement is not used as a driver of strategy, because it does not indicate how the institutions want to ensure their survival. Studying broader aspects (documents of the institutions and available data at INEP and MEC), Koppe (2014) found that private for-profit institutions in RS can be differentiated by their operating strategy (cost leadership, differentiation and geographical focus). 
We identified Philosophy in 67 of the 91 mission statements studied (74\%), especially in university colleges or centres and public institutions, in which this element is present in $100 \%$ and $90 \%$ of HEls, respectively. The outcomes are similar to those identified by Pearce and David (1987), for whom $75 \%$ of the analysed mission statements showed this element, higher than the percentages identified by King, Case and Premo (2012), which were only $25 \%, 14 \%, 8 \%$ and $8 \%$ in studies performed in $2001,2008,2010$ and 2011 , respectively.

In general, the philosophy of HEls is aligned with the features defined by the regulatory instances regarding the role of colleges, university colleges or centres, universities and federal institutes (Sinaes, 2004). Table 2 shows this alignment.

Table 2

Mission statement Characteristics by type of institution

\begin{tabular}{l|l|l}
\hline $\begin{array}{l}\text { Academic } \\
\text { configuration }\end{array}$ & Features & Examples of mission statement \\
\hline College & Early form of accreditation & "Promote education..." \\
"Educating to work...." \\
\hline $\begin{array}{l}\text { University College or } \\
\text { Centre }\end{array}$ & $\begin{array}{l}\text { Multi curricula institutions } \\
\text { characterized by excellence in } \\
\text { teaching }\end{array}$ & $\begin{array}{l}\text { "Foster integral and continued education of the person, } \\
\text { through education, research and social and cultural } \\
\text { development of excellence..." }\end{array}$ \\
\hline \multirow{2}{*}{ University } & $\begin{array}{l}\text { Qualifying higher education } \\
\text { professionals, developing } \\
\text { research, social and cultural } \\
\text { development and cultivating } \\
\text { human knowledge }\end{array}$ & $\begin{array}{l}\text { "...aimed primarily at higher education and the } \\
\text { production of philosophical, scientific, artistic and } \\
\text { technological knowledge incorporated into education, } \\
\text { research and social and cultural development.." }\end{array}$ \\
\hline \multirow{2}{*}{ Federal Institute } & $\begin{array}{l}\text { Institutions specialized in the } \\
\text { provision of vocational } \\
\text { (professional) and technological } \\
\text { education. }\end{array}$ & $\begin{array}{l}\text { "Promote vocational, scientific and technological education, } \\
\text { not paid and of excellence, on every level and modalities, } \\
\text { through the articulation between education, research and } \\
\text { social and cultural development." }\end{array}$ \\
\hline
\end{tabular}

Source: Structured by the authors.

Most of the mission statements of the colleges include aspects related to the offer of education, as they do not feature, among their objectives, the development of research and social and cultural projects. However, the mission statements of university colleges or centres emphasize the philosophy of providing quality education, and those of universities include aspects related to the production and dissemination of knowledge, integrating education research and social and cultural projects. Predictably, general mission statements reflect academic categories. It is important to highlight that eleven colleges, two federal institutes and a university college or centre insert the term research in their mission statement assignment, even though there is no legal requirement to do so.

The regulation of MEC determines some core elements of the mission statement. Perhaps because of this, there is no concern for most of the institutions to define the desired public image in the mission statement. In our research, we found only nine colleges that include a public image in their mission statement, differing from the findings of Mussoi, Lunkes and Silva (2011) who state that the public image is present in $94 \%$ of mission statements. An example of a mission statement that clearly describes the desired public image is "to be a reference institution in the areas of education and research".

While the public image is rarely present in the mission statements, the way institutions see themselves appears more frequently (38\%), mainly in federal institutes (67\%). This finding is similar to that stated by Mussoi, Lunkes and Silva (2011) where the self-image is found in 30\% of mission statements, and by Gonzaga et al. (2015), who identified $42 \%$. However, these frequencies are lower than the references to the desired public image found by Teles and Lunkes (2009) in $64 \%$ of the mission statements of the companies they studied.

The geographic domain is related to the profile of the institution, and is present when there is a predominantly regional operation. Quotes like "community where it operates" and "society in which it operates" support this analysis. There are 14 institutions that include the place of operation in their mission statements $(16 \%$ of total). Previous research identified ambiguous results, because, depending on the profile of the companies surveyed, this element is quoted frequently (Williams, 2008; Rarick \& Nickerson, 2006) Or Not (King, Case, \& Premo, 2012; Forte \& Pereira, 2003; Souza, Coral, \& Lunkes, 2014). 


\subsection{Normative issues and the model of Pearce and David}

During the analysis process, we identified new mission statements that had not been proposed by Pearce and David (1987): graduates' profiles; (53) and contribution of the institution to the community/region (29). Considering the significance of these statements, we propose adding these statements to the conceptual model to be used by HEls. We grouped both statements under a new element defined as normative issues. The option to include normative issues has different reasons: the two statements are present in a considerable number of mission statements; they are important for HEls' strategies, and they are required by the normative regulations that govern HEls in Brazil.

The Brazilian Law of Directives and Bases (Law 9394/96) defines that higher education aims: to stimulate cultural production and scientific research; to graduate students qualified for inclusion in professional sectors; to stimulate the desire for constant cultural and professional improvement; to encourage knowledge of the current affairs worldwide, and to promote executive education, social and cultural projects, etc. By observing these targets more carefully, we notice that the graduates' profile and the institutions' contribution to the community/region stems largely from this text. Moreover, many mission statements are aligned with the economic, social, cultural, and research \& development context of the region and nation, elements which had been defined as mandatory by the National Higher Education Evaluation System (Sinaes, 2004), by the Institutional Development Plan (Pdi, 2006) and consequently, by the institutional assessment instruments (Inep, 2015).

For both statements, the most common word was development, followed by professionals and society. Educational institutions' mission statements show a broad concern for the environment in which they operate, describing the kind of professionals they desire to train, and how they can contribute to the environment. From the 91 mission statements studied, 53 describe graduate profile. Public institutions $(70 \%)$ and universities $(68 \%)$ describe it more frequently.

There were no significant differences between the approaches to the graduates' profile. In all (academic configuration and administrative category) groups there are institutions dedicated to the formation of a highly professional profile, as can be seen in this excerpt: "professional entrepreneurs for the labour market." Issues related to social and environmental responsibility also appear in all groups, "forming entrepreneurs who are ethical and committed to the development of the country".

In our study, we obtained a similar conclusion analyzing the contribution to the community/region. Institutions of all groups have this element in their mission statements, with similar texts. The development of the society as a whole is the main focus, "Aiming at the development of a fair and fraternal society" "strengthening community ties, expanding education in less-favoured areas through actions that foster life" and the University Colleges or Centres (60\%) and public institutions (40\%) cited this item more often.

\subsection{A consolidated analysis}

By comparing the mission statements individually, we identified significant differences among them. Some emphasize normative issues, others, the philosophy or type of service, among others. Fitzgerald and Cunningham (2016) identified service types (100\%) and market or consumers $(90 \%)$ as the elements present in statements of HEls mission statement of Ireland. Table III presents the frequency of the elements in HEls organized by the academic organization.

Table 3

Frequency of elements by academic organization

\begin{tabular}{l|c|c|c|c|c}
\hline \multicolumn{1}{c|}{ Element } & College & $\begin{array}{c}\text { Federal } \\
\text { Institute }\end{array}$ & $\begin{array}{c}\text { University } \\
\text { College or } \\
\text { Centre }\end{array}$ & University & $\begin{array}{c}\text { Average } \\
\text { presence }\end{array}$ \\
\hline Normative issues & $73 \%$ & $100 \%$ & $100 \%$ & $89 \%$ & $79 \%$ \\
\hline Philosophy & $66 \%$ & $67 \%$ & $100 \%$ & $95 \%$ & $74 \%$ \\
\hline Service Type & $53 \%$ & $100 \%$ & $40 \%$ & $16 \%$ & $46 \%$ \\
\hline Self concept & $41 \%$ & $67 \%$ & $20 \%$ & $32 \%$ & $38 \%$ \\
\hline Market or consumers & $27 \%$ & $33 \%$ & $0 \%$ & $21 \%$ & $24 \%$ \\
\hline
\end{tabular}


(Conclusion)

\begin{tabular}{l|c|c|c|c|c}
\hline Element & College & $\begin{array}{c}\text { Federal } \\
\text { Institute }\end{array}$ & $\begin{array}{c}\text { University } \\
\text { College or } \\
\text { Centre }\end{array}$ & University & $\begin{array}{c}\text { Average } \\
\text { presence }\end{array}$ \\
\hline Geographic domain & $17 \%$ & $0 \%$ & $0 \%$ & $16 \%$ & $15 \%$ \\
\hline Public image & $14 \%$ & $0 \%$ & $0 \%$ & $0 \%$ & $10 \%$ \\
\hline Survival, growth and profit & $8 \%$ & $67 \%$ & $0 \%$ & $0 \%$ & $8 \%$ \\
\hline Technology & $0 \%$ & $0 \%$ & $0 \%$ & $5 \%$ & $1 \%$ \\
\hline
\end{tabular}

Source: Elaborated by the authors.

Considering the groups of institutions, only the Federal Institutes have some regularity, where part of the elements is present in $67 \%$ of mission statements. The development of these institutes is recent in Brazil, which may explain the homogeneity of their mission statements. This outcome is close to the encountered by Freitas et al. (2011), who identified service type in 90\% of the mission statements of the Federal Institutes.

In studies evaluating the effectiveness of the mission statement in educational institutions (Freitas et al., 2011; Forte \& Pereira, 2003; Stemler, Bebell, \& Sonnabend, 2011; Ellis \& Miller, 2014), no element was found in $100 \%$ of the mission statements. In our study, only the service type appears in $100 \%$ of the mission statements of the federal institutes, and philosophy appears in $100 \%$ of University Colleges or Centres, but we did not find any element that was common to all the mission statements studied.

Although we found each element at least once in nearly all groups, this occurs unevenly. Mission statements of University Colleges or Centres are the most incomplete, with only three of the elements mentioned by Pearce and David. Among the colleges, only technology was not identified in any of their mission statements, making this the most complete group.

When comparing the mission statements by administrative category, it is clear that the self-concept is equally important for all the institutions. The element that confers greater differentiation is the service type (Table 4).

Table 4

Frequency of elements by administrative category

\begin{tabular}{l|c|c|c|c}
\hline \multicolumn{1}{c|}{ Element } & Public & Private non-profit & Private for-profit & $\begin{array}{c}\text { Average } \\
\text { Presence }\end{array}$ \\
\hline Normative issues & $90 \%$ & $79 \%$ & $75 \%$ & $79 \%$ \\
\hline Philosophy & $\mathbf{9 0 \%}$ & $70 \%$ & $75 \%$ & $74 \%$ \\
\hline Service Type & $60 \%$ & $36 \%$ & $61 \%$ & $46 \%$ \\
\hline Self concept & $40 \%$ & $38 \%$ & $39 \%$ & $38 \%$ \\
\hline Market or consumers & $20 \%$ & $28 \%$ & $18 \%$ & $24 \%$ \\
\hline Geographic domain & $20 \%$ & $11 \%$ & $21 \%$ & $15 \%$ \\
\hline Public image & $0 \%$ & $13 \%$ & $7 \%$ & $10 \%$ \\
\hline Survival, growth and profit & $20 \%$ & $4 \%$ & $11 \%$ & $8 \%$ \\
\hline Technology & $0 \%$ & $2 \%$ & $0 \%$ & $1 \%$ \\
\hline Soce:
\end{tabular}

Source: Elaborated by the authors.

Considering these groups, no significant variations were identified in the comparison of elements by administrative category. The element with the second highest inequality is philosophy, with $70 \%$ to $90 \%$. Mission statements differ more when the comparison is between colleges, university colleges or centres, federal institutes and universities, than when administrative categories are compared: public, private non-profit and for-profit.

For Pearce (1982), the mission statement elements are targeted at two groups; the internal public (individuals and groups who are shareholders or employees) and the external public (all other individuals and groups affected by the company's actions: customers, suppliers, governments, unions, competitors, local communities and the public). According to the author, each of these interest groups has reasons to expect and seek their satisfaction. In this sense, a predominantly external focus was identified in the mission statements 
investigated, based on the presence of a higher proportion of elements such as normative issues, graduates' profile and type of service offered.

In relation to the effectiveness of the mission statement, Figure 2 shows the results of the comparison between the number of elements identified in the mission statement of each educational institution. For analytica; purposes, we considered the presence of the elements proposed by Pearce and David (1987), and also the normative issues (graduates' profile and contribution to society).

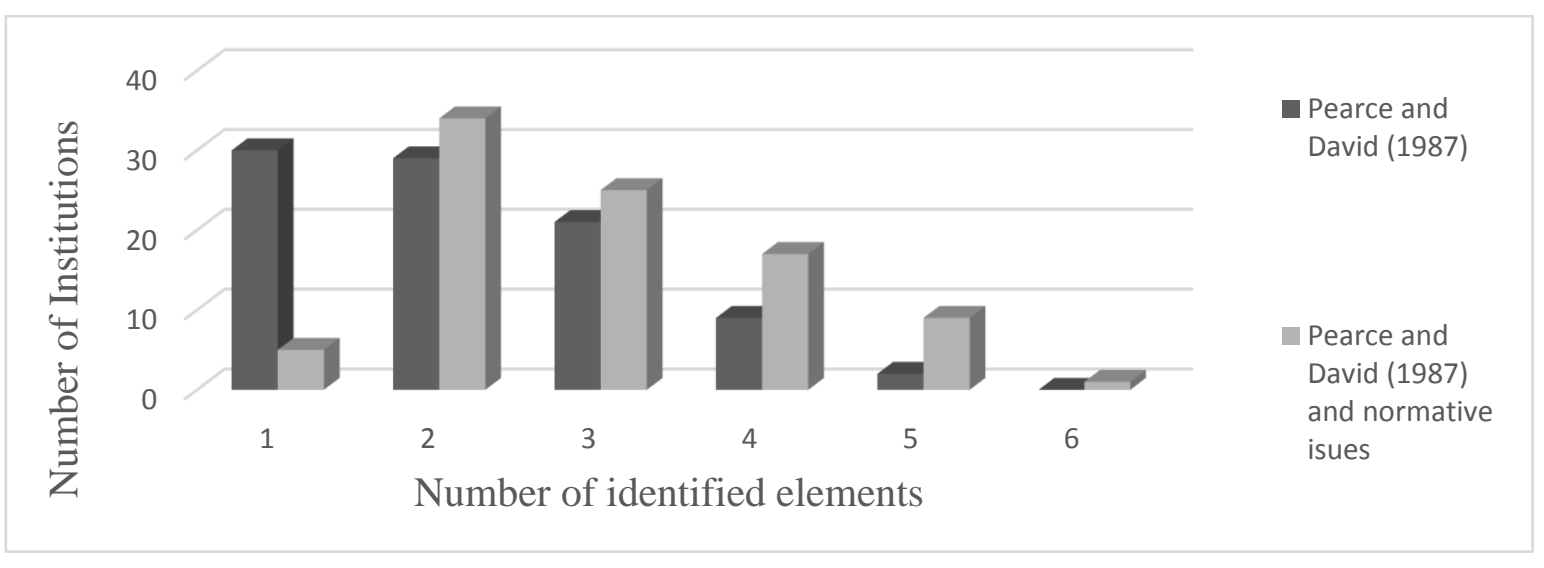

Figure 2: Number of elements by mission statement Source: Elaborated by the authors.

The average number of elements identified is 2.14 , considering only the ones proposed by Pearce and David, and 2.93 with the addition of the element normative issues. Only two mission statements have five elements, and none have seven or eight. The highest concentration is in the institutions that describe only 1 or 2 elements, revealing that there is no evolution in the effectiveness of the use of the mission statement. These results are similar to those of Mussoi, Lunkes and Silva, (2011), Teles and Lunkes (2009) and Souza, Coral and Lunkes (2014).

Previous studies (Forte \& Pereira, 2003; Stemler, Bebell, \& Sonnabend, 2011; Ellis \& Miller, 2014) showed that the mission statement does not meet the general purposes of educational institutions, nor is not being used as a driver of strategy, as suggested by the belief system. The low number of elements per institution and a consequent lack of information regarding how institutions aim to achieve their strategic objectives show that in the majority of institutions, the mission statement cannot be regarded as a strategic tool.

\section{CONCLUDING REMARKS}

Mission statements describe key characteristics of businesses including their purpose, strengths, values, critical interests and goals/core objectives (King, Case, \& Premo, 2012). The HEls' mission statements enable interested parties to reflect on its purpose in relation to their main objectives (Stemler, Bebell, \& Sonnabend, 2011) and the desired strategy. Moreover, in Brazil, it became a mandatory element of the Institutional Development Plan of the HEls. This makes mission statements important to HEI managers because these statements reveal what the institution will be and what the institution offers to internal and external stakeholders.

In order to identify whether the mission statement is used to guide the implementation of the strategy, this paper studied the mission statements of HEls in RS. Of the 129 institutions surveyed, almost $80 \%$ had a mission statement published on their websites, showing that the majority develop their mission statements and make them available to the public.

The hermeneutic analysis of the mission statements of all HEls revealed a rich linguistic range, in which the most commonly used words are: development, promotion, education, knowledge and society. This shows that the mission statements are aligned with the fundamental purposes of higher education in Brazil, which is to convey, produce, spread knowledge and promote economic and social development (Sinaes, 2004).

The analysis of whether mission statements are effective drivers of the strategic planning adopted the mission statement assessment model proposed by Pearce and David (1987), with the two elements that we added after our exploratory analysis. Philosophy, type of service, and self-concept are the elements adopted most frequently, although only the first element is identified in more than $50 \%$ of the mission statements. The average 
number of elements is 2.14 . Only two mission statements feature 5 elements, and none feature 7 or 8 . This outcome supports the conclusion that although present in institutions, the mission statement does not include all the information considered necessary to the strategic planning process and its operationalization. That is, the role of the mission statement as a driver of the strategy is not entirely fulfilled. Mission statements mainly describe aspects related to what they represent, e.g. self-concept and philosophy, and neglect elements such as technology, growth, survival and desired public image. HEls also fail to define important elements related to what they intend to be and achieve, choosing instead to express what they already are and represent. The description of these elements could also be more objective. For example, when an HEl states that it offers "education" or "teaching", it is unclear whether these terms are related to the undergraduate, graduate or continuing education levels. The same is true of consumers. "People" or "community" are generic expressions that do not identify the specific public to whom HEls are addressing their services. Therefore, a greater number and clearer elements could contribute to a better formulation of mission statements that reflect the objectives of HEls.

It is important that managers align mission statements with the IES strategy. This will enable them to guide the decision-making processes and actions of employees, faculty and academic coordinators more effectively. After all, mission statements that address all elements help to legitimize HEls with internal stakeholders (Fitzgerald \& Cunningham, 2016). Also, there are normative guidelines that guide the alignment between the strategic planning and the mission statement, observing the coherence and articulation between the different actions (Mec, 2012). This reinforces the importance of managers directing their efforts to ensuring that mission statements are not only formulated to meet a legal requirement but also to enable these statements to fulfill their primary role of guiding the strategy, considering the different academic and administrative configurations of HEls.

Our analysis of the mission statements showed that in addition to the eight elements of Pearce and David's model, the graduates' profile and contributions to the community are frequently used. These statements are distinguishing features in higher education. Although the service provided is mainly centered around education, the most significant influence in society occurs through the actions of graduates. This may be one of the reasons why HEls include these aspects in their mission statements, even though they are not present in those of other industries. The other reason is from the mandatory regulations that govern Brazilian HEls. As both statements stemmed from the norms concerning the mission statement definition of HEls, they were grouped in a new element called normative issues, which has been added to Pearce and David's model. We consider this the most important theoretical contribution of our study because normative issues could be relevant to organizations operating in other regulated economic sectors, e.g. for example, healthcare and finance.

Although Pearce and David (1987) present important elements for the effectiveness of a mission statement, the objective of this analysis was not to establish an ideal model; especially because there is no consensus in the literature regarding what should be included in a mission statement. In addition to the model chosen, others can be used and may lead to different results. For some organizations, a simple statement is suitable, for others values, the addition of the company's philosophy and customers is indispensable (Abrahams, 2013).

This work is limited to the study of mission statements of HEls in Rio Grande do Sul. Consequently, the results cannot be generalized for all Brazilian HEls or for HEls abroad. Also, the inherent subjectivity of the codification process should be considered a limitation. Thus, even using the same data, other researchers may obtain different results from the ones presented here.

Concerning future studies, we suggest the analysis of the mission statements of institutions from other countries, where the regulations for the sector are more, or less strict. These studies should provide greater consistency, identifying possible regional geographical features. Finally, as the conceptual model adopted has not foreseen particular elements for different industries, additional studies can be conducted with the addition of normative elements added.

\section{REFERENCES}

Abrahams, J. (2013). 101 mission statements from top companies. Ten Speed Press, Toronto.

Allison, J. (2017). Advancing strategic communication through mission statements: creation of a natural language taxonomy. Academy of Strategic Management Journal, 16, (3). 
Alshameri, F., Greene, G. R., \& Srivastava, M. (2012). Categorizing top fortune company mission and vision statements via text mining. International Journal of Management \& Information Systems (Online), 16(3), 227.

Araújo Júnior, R. H., \& Tarapanoff, K. (2007). Precisão no processo de busca e recuperação da informação: uso da mineração de textos. Ciência da informação, 35(3).

Atenstaet, R. (2012). Word cloud analysis of the BJGP. British Journal of General Practice, 62(598), 148.

Ayers, D. F. (2015). Credentialing structures, pedagogies, practices, and curriculum goals: Trajectories of change in community college mission statements. Community College Review, Raleigh, 43(2), 191-214.

Bardin, L. (2011). Análise de conteúdo. São Paulo. Edições 70.

Bart, C. K. (2006). Mission profitable. The Canadian Manager, Ontario, 31(3), 20.

Bartkus, B. R., \& Glassman, M. (dec. 2008). Do Firms Practice What They Preach? The Relationship Between Mission Statements and Stakeholder Management. Journal Of Business Ethics, Amsterdam, 83(2), 207216.

Braga, R.; Monteiro, C. (2005). Planejamento estratégico sistêmico para instituições de ensino. São Paulo, Hoper.

Campbell, A. (1997). Mission Statements. Long Range Planning, 30(6), 931-932.

Castro, A. de. (2014). Gestão financeira: a sustentabilidade financeira e a interação acadêmica nas instituições de ensino superior. In Gestão Universitária: Os Caminhos para a Excelência, Porto Alegre.

Comung, Instituições Comunitárias. Available at: <http//www.comunitarias.org.br/site/index.php>. Accessed on July 13, 2015.

Dörtyol, I., T. (2015). Exploring The Marketing Philosophy Through Mission Statements: A Study On Capital 500. Üzerine Bir Araştirma. Öneri Dergisi, 11(44), 189-203.

Drucker, P. F. (1986). Management: tasks, responsibilities and practices. New York: Harper \& Row. Available at: https://www.google.com.br/\#q=Management:+tasks +responsibilities +and+practices\&*. Accessed on September 13, 2016.

Drucker, P. (1983). Management: Tasks, responsibilities, practices. New York. Harper \& Row.

Espartel, L. B. (2009). O uso da opinião dos egressos como ferramenta de avaliação de cursos: o caso de uma instituição de ensino superior catarinense. Revista Alcance, 16(1).

Ellis, J., \& Miller, P. (2014). Providing Higher Education in Post-modern Times: what do university mission statements tell us about what they believe and do? Research in Comparative and International Education, Oxford, v. 9, n. 1, p. 83-91. 2014.

e-MEC - Sistema de Avaliação do Ensino Superior. (2016). Cadastro e-MEC de Instituições e Cursos de Educação Superior. Available at: http://emec.mec.gov.br/. Accessed on July 15.

Fauzi, H., \& Rahman, A. A. The role of control system in increasing corporate social performance: The use of levers of control. Issues in Social and Environmental Accounting, Kota Surakarta, n. 2, v. 1, p. 131-144. 2008.

Fitzgerald, C., \& Cunningham, J. A. (2016). Inside the university technology transfer office: mission statement analysis. The Journal of Technology Transfer, 41(5), 1235-1246.

Forte, S. H. A. C., \& Pereira, M. S. (2010). A construção e disseminação da missão nas instituições de ensino superior no Ceará. Revista Gestão e Tecnologia, Pedro Leopoldo, 2(1).

Freitas, C. L. De, Espindola, E. E., Lunkes, R. J, \& Pfitscher, E. D. (2011). Missão institucional: análise nas instituições federais de ensino superior (IFES). Anais do Congresso Ufsc de Controladoria e Finanças, Florianópolis, SC, 4.

Gonzaga, R. P., Cruz, A. P Da, Pereira, C. A., \& Luz, A. T. M. da. (2015). Associação entre Missão Institucional Declarada por Empresas Brasileiras e seus Indicadores de Desempenho. Contabilidade Vista \& Revista, Belo Horizonte, I(26), 15-34.

Inep (2015). Instrumento de Avaliação Institucional Externa: Subsidia os atos de credenciamento, recredenciamento e transformação da organização acadêmica (presencial). Available at: 
http://download.inep.gov.br/educacao_superior/avaliacao_institucional/ instrumentos/2014/instrumento_institucional.pdf._Accessed on November 6, 2016.

King, D. L., Case, C. J., \& Premo, K. M. (2012). An international mission statement comparison: United States, France, Germany, Japan, and China. Academy of Strategic Management Journal, London, 11(2), 93-119.

Koppe, L. R. (2014). Instituições de ensino superior privadas no Brasil: o caso das instituições de ensino privadas com fins lucrativos no Rio Grande do sul. Tese de Doutorado em Sociologia, Instituto de Filosofia e Ciências Humanas, Universidade Federal do Rio Grande do Sul, Porto Alegre.

Lei no 11.892, from December 29, 2008. (2008). Institui a Rede Federal de Educação Profissional, Científica e Tecnológica, cria os Institutos Federais de Educação, Ciência e Tecnologia, e dá outras providências. Available at http://www.planalto.gov.br/ccivil_03/_ato2007-2010/2008/lei//11892.htm. Accessed on April 11, 2018.

Ldb (1996). Brazilian Law of Directives and Bases (Law 9394/96). Available at: http://portal.mec.gov.br/seesp/arquivos/pdf/lei9394_Idbn1.pdf. Accessed on August, 10, 2017.

Leggat, S. G., \& Holmes, M. (2015). Content analysis of mission, vision and value statements in Australian public and private hospitals: Implications for healthcare management. Asia Pacific Journal of Health Management, Gladesville, 10(1), 46.

Morais, N., Pombo, L., Batista, J., Moreira, A., \& Ramos, F. (2014). Uma revisão de literatura sobre o uso das tecnologias da comunicação no ensino superior. Revista Prisma.Com, (24), 162-185.

Mussoi, A., Lunkes, R. J., \& Silva, R. V. Da. (2011). Missão institucional: uma análise da efetividade e dos principais elementos presentes nas missões de empresas brasileiras de capital aberto. REGE-Revista de Gestão, São Paulo, 18(3), 361-384.

Oliveira, J. (2015). Saiba como funciona sistema de ensino superior no Brasil. Available at http://www.brasil.gov.br/educacao/2009/11/ensino-superior. Acessed on July, 23, 2015.

Oye, N. D., lahad, N. A., \& Rahim, N. (2014). Ab. The history of UTAUT model and its impact on ICT acceptance and usage by academicians. Education and Information Technologies, Laxenburg, 19(1), 251-270.

Paiva, R. C. V. De, Barbosa, F. V., Gonçalves, R. G., \& Costa, D. de M. (2014). Educação Superior Privada: Um Estudo do Desempenho Financeiro em nove Instituições de Ensino Superior. Revista Gestão \& Tecnologia, Pedro Leopoldo, 14(1), 68-99.

Palmer, T. B., \& Short, J. C. (2008). Mission statements in US colleges of business: An empirical examination of their content with linkages to configurations and performance. Academy of Management Learning \& Education, 7(4), 454-470.

Pearce, J. A.; David, F. Corporate mission statements: The bottom line. The Academy of Management Executive, v. 1, n. 2, p. 109-115. 1987.

Pearce, J. A. (1982). The company mission as a strategic tool. Sloan Management Review, Cambridge, 23(3), 15.

Penco, L., Profumo, G., \& Scarsi, R. (2017). Stakeholder Orientation in Cruise Lines' Mission Statements. Sustainability, 9(11), 2151.

Rarick, C. A., \& Nickerson, I. (2006). An empirical analysis of web-based corporate mission statements. Journal of Strategic E-commerce, Reno, 4(1/2), 1.

Sinaes. (2004). Law 10.861, April 14, 2004. Institui o Sistema Nacional de Avaliação da Educação Superior SINAES e dá outras providências. Available at: http://portal.inep.gov.br/sinaes. Accessed on April, 10, 2018.

Souza, P. De, Coral, S. M., \& Lunkes, R. J. (2014). Missão Organizacional: Análise dos Principais Elementos Propostos por Pearce II (1982) Presentes nas Missões dos Hotéis do Sul do Brasil. PODIUM Sport, Leisure and Tourism Review, São Paulo, 3(1), 94.

Stemler, S. E., Bebell, D., \& Sonnabend, L. A. (2011). Using School Mission Statements for Reflection and Research. Educational Administration Quarterly, New York, 47(2), 383-420. 
Teles, J., \& Lunkes, R. J. (2011). Efetividade da missão institucional: um estudo nas 100 maiores empresas de capital aberto no Brasil. Anais de Congresso da Associação Nacional dos Programas de Pós-Graduação em Contabilidade, Vitória.

Want, J. H. (Aug. 1986). Corporate mission. Management Review, 75(8), 46-50.

Williams, L. S. (2008). The mission statement: A corporate reporting tool with a past, present, and future. Journal of business communication, New Jersey, 45(2), 94-119 